\title{
Diatom analysis of sediments of Lake Big Miassovo of South Ural (Russia)
}

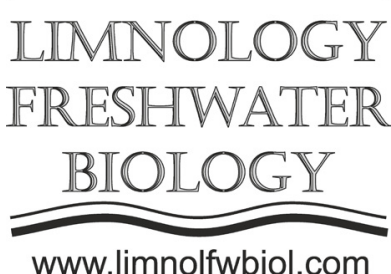

\author{
Valieva E.A., Frolova L.A., Kuzina D.M., Nurgaliev D.K. \\ Institute of Geology and Petroleum technologies, Kremlevskaya str. 4/5, Kazan, 420111, Russia
}

\begin{abstract}
Diatoms are generally used to infer environmental changes. The purpose of this work is to study the taxonomic composition and ecological features of diatoms in the palaeoarchives from Lake Big Miassovo (South Ural, Russia). A core was taken in the deepest part of Lake Big Miassovo in July 2018. The core covered the time span in 13500 years. The diatom analysis of 51 samples revealed 124 taxa from 47 genera. The highest number of species was observed for Epithemia. The analysis of the ecological structure of this diatom assemblage shows that it is dominated of cosmopolitan, alkaliphilic benthic, and oligogalobic species with the growth under the moderate temperatures. The prevalence of Handmannia comta (Ehren.) Kociolek \& Khursevich emend. Genkal in the sediments was established. The sub-dominant species were Amphora pediculus (Kutz.) Grun., Karayevia clevei (Grun.) Bukht., Aulacoseira ambigua (Grun.) Simon., Pseudostaurosira brevistriata (Grun.) D.M. Williams \& Round, Stephanodiscus alpinus Hust. in Hub.-Pest.
\end{abstract}

Keywords: Diatoms, Big Miassovo Lake, bottom sediments, South Ural, climate

\section{Introduction}

Lake sediments are the most trustworthy archives containing data on environmental changes. The study of lake sediments allows us to reconstruct abiotic and biotic conditions of lake and its surrounding area (Evans and Heller, 2003). Biological paleoindicators such as diatoms, remains of vascular plants and invertebrates (cladocera, chironomidae, ostracoda), spores and pollen used for more accurate qualitative and quantitative reconstruction of past conditions in lakes (Frolova, 2018). The border location of the Urals, as the climate divide, makes paleoecological and paleoclimatic investigations of Big Miassovo lake especially important (Maslennikova et al., 2014). Lake Big Miassovo is located on the territory of the Ilmensky Nature Reserve. It is a tectonic lake stretching from north to south along the eastern foot of the Ilmensky Ridge. Its total area is $11.4 \mathrm{~km}^{2}$, length $-8 \mathrm{~km}$, average width $-1.5 \mathrm{~km}$. A large number of bays and diversity of coast shapes determine the highly indented coastline. The maximum depth of the lake is $25 \mathrm{~m}$ (the average depth is $11.2 \mathrm{~m}$ ). The water volume is 128.5 million $\mathrm{m}^{3}$. The lake waters are fresh, their mineralization does not exceed 200 mg/l (Nurgaliev et al., 2018).

\section{Material and methods}

A core no. $3\left(55^{\circ} 09^{\prime} 51.1^{\prime \prime} \mathrm{N}\right.$; $\left.60^{\circ} 17^{\prime} 21.9^{\prime \prime} \mathrm{E}\right)$ from Lake Big Miassovo was collected in the deepest part of the lake (at the depth of $24 \mathrm{~m}$.) in July 2018. A core of $498 \mathrm{~cm}$ was obtained in the field conditions. The absolute dating of sediments was carried out by radiocarbon in the NTUAMS Lab (Department of Geosciences, National Taiwan University). All samples were processed by the standard methods using 37\% hydrogen peroxide as an oxidant of the organic matter present in the samples, including $10 \% \mathrm{HCl}$ treatment in order to remove calcium carbonate, followed by rinsing with distilled water (Battarbee, 1986). The slides were prepared with the help of high refracting Naphrax ${ }^{\circledR}$ resin $(\mathrm{RI}=1.7)$. Diatoms were identified under a Zeiss Axio Lab. A1 microscope using oil immersion at an objective magnification of $100 \times$ (1.4 n.a.). The total number of valves was considered $100 \%$. Dominant species were those, which accounted for $10 \%$ of the total amount or more; subdominants were species which accounted for 5-10\%. Diatom identification and taxonomy was based mainly on the Russian and foreign publications.

\section{Results}

The diatom analysis of 51 sediment samples revealed 124 taxa comprising the following 47. The highest number of species was observed for Epithemia. The dominant species was Handmannia comta (15.53\% of the total number of species). The subdominant species were Amphora pediulus, $(9.00 \%$ of the total number of

*Corresponding author.

E-mail address: zinnatova.1994@mail.ru (E.A. Valieva)

(C) Author(s) 2020. This work is distributed under the Creative Commons Attribution 4.0 License. 
taxa under study), Karayevia clevei (5.16\%), Aulacoseira ambigua (6.93\%), Pseudostaurosira brevistriata (6.30\%), and Stephanodiscus alpinus (5.93\%) The ecological and geographical analysis of the species composition showed the dominance of cosmopolitan, benthic, and alkaline species with the growth under moderate temperatures. With respect to $\mathrm{pH}$, the majority of the studied taxa represented the inhabitants of waters with an alkaline water reaction $(94.12 \%$ of the total number of taxa under study); $\mathrm{pH}$-indifferent and acidophilic species accounted for $2.94 \%$ of the total number of taxa under study, respectively. Considering the geographical distribution, most of the species were assigned to cosmopolites $-62.50 \%$ of the total number of taxa under study - and $37.50 \%$ of the taxa belonged to the Holarctic species. In terms of the temperature factor, the analyzed diatoms were characterized as favoring moderate temperature conditions; the only cold-loving species were Stephanodiscus alpinus and Halamphora oligotraphenta (Lange-Bertalot) Levk. With respect to the trophic status, mesotrophic-eutrophic (30.49\% of the total number of taxa under study) and oligotrophicmesotrophic species $(26.83 \%)$ were dominant, oligotrophic species made $13.41 \%$, indifferent species represented $14.63 \%$, oligotrophic-eutrophic species $6.10 \%$, mesotrophic species made $4.89 \%$ and eutrophic taxa were the least numerous - 3.66\%. Among diatom algae, benthic species prevailed in the habitat $-52.46 \%$. They were followed by plankton-benthic species $39.34 \%$ and plankton species $-8.20 \%$.

\section{Conclusions}

As a result of the study, 124 diatom taxa comprising 47 genera were identified in the fossil diatom flora. The ecological and geographical analysis of the species composition showed the dominance of alkaline, benthic, and cosmopolitan species. The characteristics of the described diatom communities show that Big Miassovo lake was a shallow oligotrophic-mesotrophic water body in the early stage of sedimentation. Then, under the conditions of climate warming and lake deepening, the abundance and diversity of diatoms in the communities and the proportion of planktonic species increased.

\section{Acknowledgements}

We are grateful to all the participants of the expedition for their assistance in organizing and carrying out the field work. The work was funded by the subsidy allocated to Kazan Federal University for the state assignment in the sphere of scientific activities. The field work was supported by the Russian Science Foundation (project no. 18-17-00251).

\section{References}

Battarbee R.W. 1986. Diatom analysis, in Handbook of Holocene Paleoecology and Palaeohydrology. In: Berglund B.E. (Ed.). New-York Wiley, pp. 527-570.

Evans M. E., Heller F. 2003. Environmental magnetism: Principles and applications of enviromagnetics, San Diego: Academic Press.

Frolova L.A. 2017. Cladocera from bottom deposits as an indicator of changes in climate and ecological conditions. IOP Conference Series: Earth and Environmental Science 107: 1-4. DOI:10.1088/1755-1315/107/1/012084.

Maslennikova A.V., Udachin V. N., Deryagin V.V. 2014. Paleoekologiya i geokhimiya ozernoi sedimentatsii golotsena Urala [Paleoecology and geochemistry of lake sedimentation of the Holocene of the Urals]. Ekaterinburg: RIO UrO RAN. (in Russian)

Nurgaliev D., Kuzina D., Kosareva L. et al. 2018. Paleolomnological investigations of lake Bolshoe Miassovo (Chelyabinsk region, Russia) 18th International Multidisciplinary Scientific GeoConference SGEM2018: 331-338 DOI: 10.5593/sgem2018V/4.3/S06.039 